\title{
CHILD LABOR IN CAR-REPAIR WORKSHOPS: SOCIO-DEMOGRAPHIC CHARACTERISTICS AND HEALTH HAZARDS
}

\author{
By \\ Elghazally SA ${ }^{1}$, Ahmed $\mathrm{SM}^{1}$, Ali $\mathrm{HR}^{2}$ and Ibrahim $\mathrm{AK}^{1}$ \\ ${ }^{1}$ Department of Public Health and Community Medicine, Faculty of Medicine, Assiut University, \\ Assiut, ${ }^{2}$ Ministry of Health, Assiut.
}

Corresponding author: ElghazallySA: e-mail:shima_dola@aun.edu.eg

DOI: 10.21608/ejom.2021.83814.1241

Submit date: 2021-07-03

Revise date: $2021-07-27$

Accept date: 2021-07-28

Authors Contributions: Elghazally SA and Ahmed SM: concept, design, literature search, manuscript preparation, editing and review. Ali HR: literature search and Data Collection. Ibrahim AK: statistical analysis, manuscript editing and final revision.

\begin{abstract}
Introduction: Child labor has serious impact on physical and psychological development of children. In addition, it affects their educational and academic performance. Aim of Work: to identify the socio-demographic characteristics of children working in car repair workshops in Al-Sadat area of Assiut city and to recognize some of its adverse health consequences. Materials and Methods: A crosssectional design study was conducted in Assiut; Egypt among 160 young workers aged 7- 17 years old currently working at car repair workshops. A structured interview questionnaire was used to assess the socio-demographic data, occupational history, work-related injuries and illnesses during last 2 years. All children were subjected to clinical and laboratory examinations. Results: About three-quarters (72.5\%) of the working children had large-sized families; their parents were illiterate/read and write ( $72.5 \%$ and $87.5 \%$ respectively). About one quarter $(22.5 \%)$ of the studied children was smokers and smoking rate was higher with increase work duration/day. Helping their families in expenditures was the most common reason for starting work (43.1\%). About $8 \%$ of the working children suffered from allergy-related symptoms especially among car painters group. The prevalence of work-related injuries was about $18 \%$ and there was positive correlate between frequency of injury and work duration. About half of the studied group was anemic (56.2\%). Conclusion and Recommendations: Children working in car repair workshops are exposed to unsafe working conditions, hence they
\end{abstract}


are at higher risk of health infirmities and work-related injuries. Enforcement of the legislation that prohibits child-work is the key solution. Parallel to this, it is important to pay more attention to the health effects of working children through performing periodic medical checkup to monitor their health and development. Also, inauguration of successful policies to promote safer work practices for young workers.

Keywords: Child Labor, Car-repair workshops, Health Hazards and Work-related injuries.

\section{Introduction}

The
Labor Organization (ILO) defines child labor as work that is mentally, physically, socially or morally harmful to children; and interferes with their education through depriving them to attend school; obliging them to premature leaving of their schools ; or requiring them to attempt to combine school attendance with long and heavy work (ILO, 2016). The latest global statistics showed that the number of children in child labor has risen to 160 million worldwide with an increase of 8.4 million children in the last four years. About 63 million girls and 97 million boys were in child labor globally at the beginning of 2020, accounting for almost 1 in 10 of all children worldwide (UNICEF /ILO, 2020). It was reported that the highest incidence of child laborers $(29 \%$ of children aged 5-17 years) in the world locate in sub-Saharan Africa (UNICEF, 2017). In developing countries, children are often forced to work in very hazardous environment for long hours per day to support the total income of their families (Radfar et al., 2018).

Hazardous child labor include functioning in a work which exposes children to physical, psychological or sexual abuse, or in environment containing dust or fumes, loud noise, extreme cold or heat, insufficient lighting or ventilation; work with dangerous tools, chemicals; and work that involves exhaustion, bending for a long time or workplaces with no bathrooms (ILO, 2016). According to this definition, about $90 \%(\mathrm{No}=1.6$ million) of the employed children in Egypt are engaged in hazardous child labor (ILO, 2018).

Machines, tools, seats, workbenches and personal protective equipment (PPE) in the work place are not designed for children. Children using these machines and tools designed for adults may develop musculoskeletal disorders and work related injuries (ILO, 1997). In addition, working children are at risk of developing anemia, malnutrition and 
mental disorders (Pasdar et al., 2014 and Ibrahim et al., 2019). Children differ in their anatomical, physiological, and psychological characteristics from adults. Thus, exposure hazards that affect adults can affect children much more strongly (Bekele and Myers, 1995).

Car repair workers have higher risk to occupational health hazards compared to workers in other occupations. They are exposed to physical hazards (ultraviolet and thermal radiation, hot environments and noise), chemical hazards (dust, fumes and dangerous chemicals), and ergonomic hazards (strenuous work postures, improperly designed tools) in addition to work in poor psychological and social environments (Vyas et al., 2011).

Different studies were conducted in many countries to study child labor and identify the factors and some health effects linked with it among automobile repair workers, but there is a lack of data to determine its magnitude among working children in Egypt especially in Assiut. Therefore, the current study is aimed to determining it.

\section{Aim of Work}

To identify the socio-demographic characteristics of children working in car repair workshops in Al-Sadat area of Assiut city and to recognize some of its adverse health consequences.

\section{Materials and Methods}

Study design: It is a descriptive cross-sectional study.

\section{Place and duration of the study:} The study was conducted at the workshops of car repair in Al-Sadat area of Assiut city. The number of these workshops was about 130. The study was conducted during the period from March to December 2020.

Study sample: The study included all children working in car repair workshops in Al-Sadat area of Assiut city, aged from 7 to 17 years who agreed to participate in the study. A total number of 160 children were recruited for this study.

\section{Study methods:}

\section{I- Self structured interview questionnaires}

Data collection was performed by using self-structured interview questionnaires. The questionnaire covered the following items:

a- $\quad$ S o c i o-d e m o gr a p h i c characteristics (age, family size, family residence, parental education 
and occupation, number of siblings and family income).

b- Occupational history: Housing conditions and occupational features, which included age at the beginning of work, duration of work, working hours/ day, weekend vacation, weekly income, causes of child work, nature of work, work hazards, type of exposure, health habits and practices such as smoking in addition to causes of school dropout. Presence of work-related injuries/ illnesses during last two years.

\section{II- General clinical examination} was conducted for every child. Height and weight were measured and were compared with the standard according to Centers for Disease Control and Prevention (CDC) guidelines. Body Mass Index (BMI) was calculated according to the formula: [weight $(\mathrm{kg}) /$ height $\left.(\mathrm{m})^{2}\right]$ (CDC, 2012), then plotted on the CDC BMI-for-age growth charts (for boys) to obtain a percentile ranking. Children were then categorized as follows: Underweight $\left(<5^{\text {th }}\right.$ percentile), normal weight $\left(5^{\text {th }}\right.$ percentile to $<85^{\text {th }}$ percentile), overweight $\left(85^{\text {th }}\right.$ to $<95$ th percentile) and obese ( $\geq 95^{\text {th }}$ percentile).

\section{III- Laboratory investigations:}

In addition, a blood sample was obtained under complete aseptic conditions for measuring hemoglobin $(\mathrm{Hb})$ level in $\mathrm{g} / \mathrm{dl}$. The children were considered anemic if their hemoglobin level was $\leq 12 \mathrm{~g} / \mathrm{dl}$ (Winham et al., 2004).

\section{Consent}

A verbal consent was taken from each child and their caregiver before data collection.

\section{Ethical Approval}

Reviewing and approval of this research was carried out via the Ethics Review Committee of Assiut Faculty of Medicine. Permission to conduct this study was obtained from the owner or the head of each workshop of car repair under study. The study was conducted in line with the Declaration of Helsinki Guidelines. STROBE statement checklist for cross-sectional studies was used to avoid bias and ensure robustness of design.

\section{Data Management}

Data entry, cleaning, and analysis were conducted via IBMSPSS-24. Descriptive statistics: means and standard deviation (SD) range, percentage $(\%)$ and frequency distributions were calculated. Test of significance: chi-square/Fisher's 
Exact test was used to compare the categorical variables. A p-value $<0.05$ differences in frequency among was considered significant.

\section{Results}

Table (1): Socio-demographic characteristics of the studied working children.

\begin{tabular}{|c|c|c|}
\hline & No. (160) & $\%$ \\
\hline \multicolumn{3}{|l|}{ Age categories: } \\
\hline $7-$ & 56 & 35.0 \\
\hline $12-17$ & 104 & 65.0 \\
\hline Age/ (years): Mean \pm SD (Range) & \multicolumn{2}{|c|}{$12.39 \pm 2.40(7-17)$} \\
\hline \multicolumn{3}{|l|}{ Residence: } \\
\hline Urban & 120 & 75.0 \\
\hline Rural & 31 & 19.4 \\
\hline Slum & 9 & 5.6 \\
\hline \multicolumn{3}{|l|}{ Education: } \\
\hline Illiterate / read and write & 27 & 16.8 \\
\hline Primary education & 58 & 36.2 \\
\hline Preparatory & 56 & 35.0 \\
\hline Secondary & 19 & 11.9 \\
\hline \multicolumn{3}{|l|}{ Fathers' education: } \\
\hline Illiterate/ read and write & 116 & 72.5 \\
\hline Primary education & 15 & 9.4 \\
\hline Preparatory education & 6 & 3.8 \\
\hline Secondary education & 23 & 14.4 \\
\hline \multicolumn{3}{|l|}{ Mothers' education: } \\
\hline Illiterate/ read and write & 140 & 87.5 \\
\hline Primary education & 6 & 3.8 \\
\hline Preparatory / secondary education & 14 & 8.7 \\
\hline \multicolumn{3}{|l|}{ Fathers' occupation: } \\
\hline Employee & 31 & 19.4 \\
\hline Skilled work & 84 & 52.5 \\
\hline Non skilled work & 16 & 10.0 \\
\hline Free work & 10 & 6.2 \\
\hline Unemployed & 9 & 5.6 \\
\hline
\end{tabular}




\begin{tabular}{|l|c|c|}
\hline Died & 10 & 6.2 \\
\hline Mothers' occupation: & & 80.6 \\
\hline Not working & 129 & 1.2 \\
\hline Work in a governmental job & 2 & 18.1 \\
\hline Work in a private job & 29 & \\
\hline Family size: & 44 & 27.5 \\
\hline$\leq 4$ & 116 & 72.5 \\
\hline$>4$ & & 53.8 \\
\hline Education of siblings > 5 years: & 86 & 8.8 \\
\hline All in education & 14 & 6.9 \\
\hline$>50 \%$ in education & 11 & 30.6 \\
\hline No one in education & 49 & \\
\hline No sibling more than 5 years & & 22.5 \\
\hline Social habits: & & 77.5 \\
\hline Smoking (cigarettes/shisha): & 36 & \\
\hline Yes & 124 & 97.5 \\
\hline NO & & \\
\hline Drug abuse & 4 & \\
\hline Yes & 156 & \\
\hline NO & & \\
\hline
\end{tabular}

Table (1) showed the distribution of the studied working children by some socioeconomic characteristics. This study included 160 children, whose ages ranged from 7 to 17 years. Children who aged $7-11$ years constituted $35 \%$ of the sample, while those who aged $12-17$ years were $65 \%$ from the studied children, with mean age in years $(12.39 \pm 2.4)$. Three fourths $(75 \%)$ of the studied group were from urban areas. As regard the educational status of children, it was found that $(36.2 \%)$ of them were in primary education, $(35.0 \%)$ in preparatory education, $(16.8 \%)$ were illiterate or can read and write. Regarding father's and mother's education, it was clear that illiteracy or just read and write counted a higher percentage (72.5\%) among fathers and (87.5\%) among mothers of working children. It was found that about half $(52.5 \%)$ of children's fathers had skilled work and the majority of working children's mothers $(80.6 \%)$ were not working. Most of the children $(72.5 \%)$ had 
family size more than 4 persons and nearly half (53.8\%) of the studied children, their all siblings more than 5 years were in education. In addition, table (1) also illustrated that $22.5 \%$ of the studied sample were smokers and $2.5 \%$ of them were drug abuser.

Table (2): Work characteristics of the studied working children.

\begin{tabular}{|c|c|c|}
\hline & No. (160) & $\%$ \\
\hline \multicolumn{3}{|l|}{ Type of child work: } \\
\hline Mechanical/ car repair & 39 & 24.4 \\
\hline Electrical workers & 30 & 18.8 \\
\hline Automotive Body Shop Painter & 48 & 30.6 \\
\hline Others* & 42 & 26.2 \\
\hline \multicolumn{3}{|l|}{ Causes of child work: } \\
\hline Help his family in expenditure & 69 & 43.1 \\
\hline Wish of the child to work & 30 & 18.8 \\
\hline Wish of the family to teach the child a craft & 61 & 38.1 \\
\hline \multicolumn{3}{|l|}{ Hours of work/day: } \\
\hline$\leq 8$ & 66 & 41.2 \\
\hline$>8$ & 94 & 58.8 \\
\hline Hours of work/ day: Mean \pm SD (Range) & \multicolumn{2}{|c|}{$9.17 \pm 1.698(6-12)$} \\
\hline \multicolumn{3}{|l|}{ Using of Personal Protective Equipment (PPE): } \\
\hline Yes & 21 & 13.1 \\
\hline NO & 139 & 86.9 \\
\hline \multicolumn{3}{|l|}{ Child income/ week (Egyptian pounds): } \\
\hline $100-199$ & 78 & 48.8 \\
\hline 200-299 & 55 & 34.4 \\
\hline$>300$ & 27 & 16.9 \\
\hline $\begin{array}{l}\text { Child income/ week: (Egyptian pounds) } \\
\text { Mean } \pm \text { SD (Range) }\end{array}$ & \multicolumn{2}{|c|}{$198.31 \pm 80.860(100-450)$} \\
\hline Mean age of starting work (range): & \multicolumn{2}{|c|}{$10.24 \pm 1.862(7-14)$} \\
\hline \multicolumn{3}{|l|}{ Quit studying: } \\
\hline Yes & 6 & 3.8 \\
\hline NO & 154 & 96.2 \\
\hline
\end{tabular}

*Others include plumber cars, tire repair labor and lathe labor. 
Table (2) showed that about one quarter of children (24.4\%) were working in car repair and in car painting (25.6\%). Helping their families in expenditures was the most common reason for starting work (43.1\%), more than half of them (58.8\%) were working more than 8 hours per day and most of them $(86.9 \%)$ were not using PPE during their work. About half of the studied working children (48.8\%) received less than 200 Egyptian pounds per week. Unfortunately, about $3.8 \%$ of them had quitted studying.

Fig. (1): Work perceptions and relation with current employer among working children .

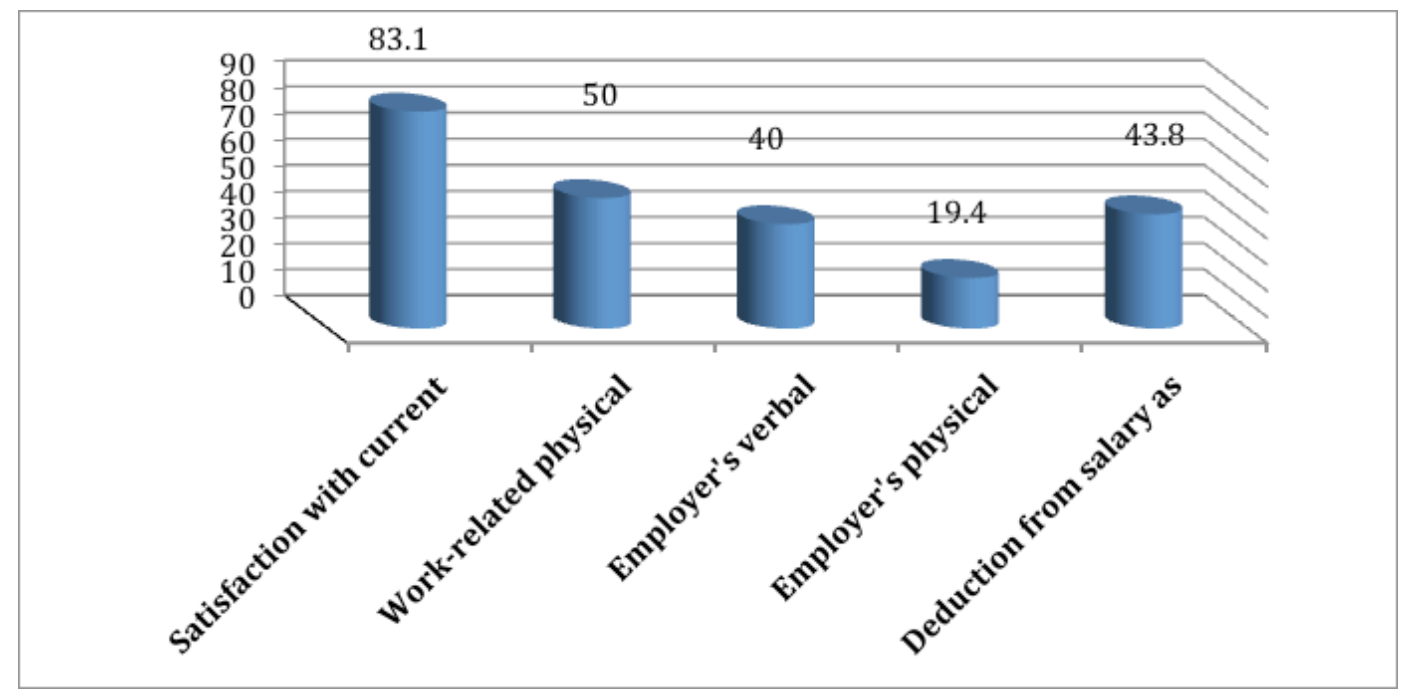

Fig. (1) showed that $83.1 \%$ of the working children were satisfied with their current job, half of them (50\%) stated that they suffer from work-related physical exhaustion. About $40 \%$ and $19.4 \%$ of the working children were exposed, to verbal and physical violence respectively (by their current employers). Deduction from salary $(43.8 \%)$ and physical or verbal violence $(38.1 \%)$ were the most common employer's attitudes toward work mistakes. 
Table (3): Pattern of health complaints, work related injuries or illness among the studied working children.

\begin{tabular}{|l|c|c|}
\hline & No. (160) & \% \\
\hline Allergy related symptoms\#: & 13 & 5.1 \\
\hline MSDs: (joint pain \& inflammations): & 90 & 56.2 \\
\hline Anemia: & & \\
\hline Weight categories: & 4 & 2.5 \\
\hline Underweight & 90 & 56.2 \\
\hline Normal weight & 39 & 24.4 \\
\hline Overweight & 27 & 16.9 \\
\hline Obese & 29 & 18.1 \\
\hline Work related injuries: & No. (\%) & \% \\
\hline Types: & $(29)(18.13 \%)$ & 31.0 \\
\hline Fracture & 9 & 6.9 \\
\hline Burn & 2 & 82.8 \\
\hline Wound & 24 & 10.3 \\
\hline Abrasion & 3 & 9.8 \\
\hline Sprain / Strain \&Joint affection & 4 & \\
\hline
\end{tabular}

\#: Allergy related symptoms (chest tightness, skin allergy, eye allergy, and allergic rhinitis).

Table (3) illustrated that $8.1 \%$ and $5.6 \%$ of the working children were suffering from allergy related symptoms and musculoskeletal disorders (MSDs) respectively. More than half of them (56.2\%) were anemic and of normal weight. The prevalence of work-related injuries was $18.13 \%$, wounds were the most frequent injuries $(82.8 \%)$, followed by fractures $(31 \%)$, then sprain/strain and joint affection $(13.8 \%)$.

There was statistically significant higher occurrence of allergy related symptoms $11(26.8 \%)$ and anemia 27(65.9\%) among painters' group. On the other hand, higher occurrence of injury was found among electrical group 9 (30\%) (Results were not tabulated). 
Table (4): Relationship between number of working hours and other background characteristics of working children.

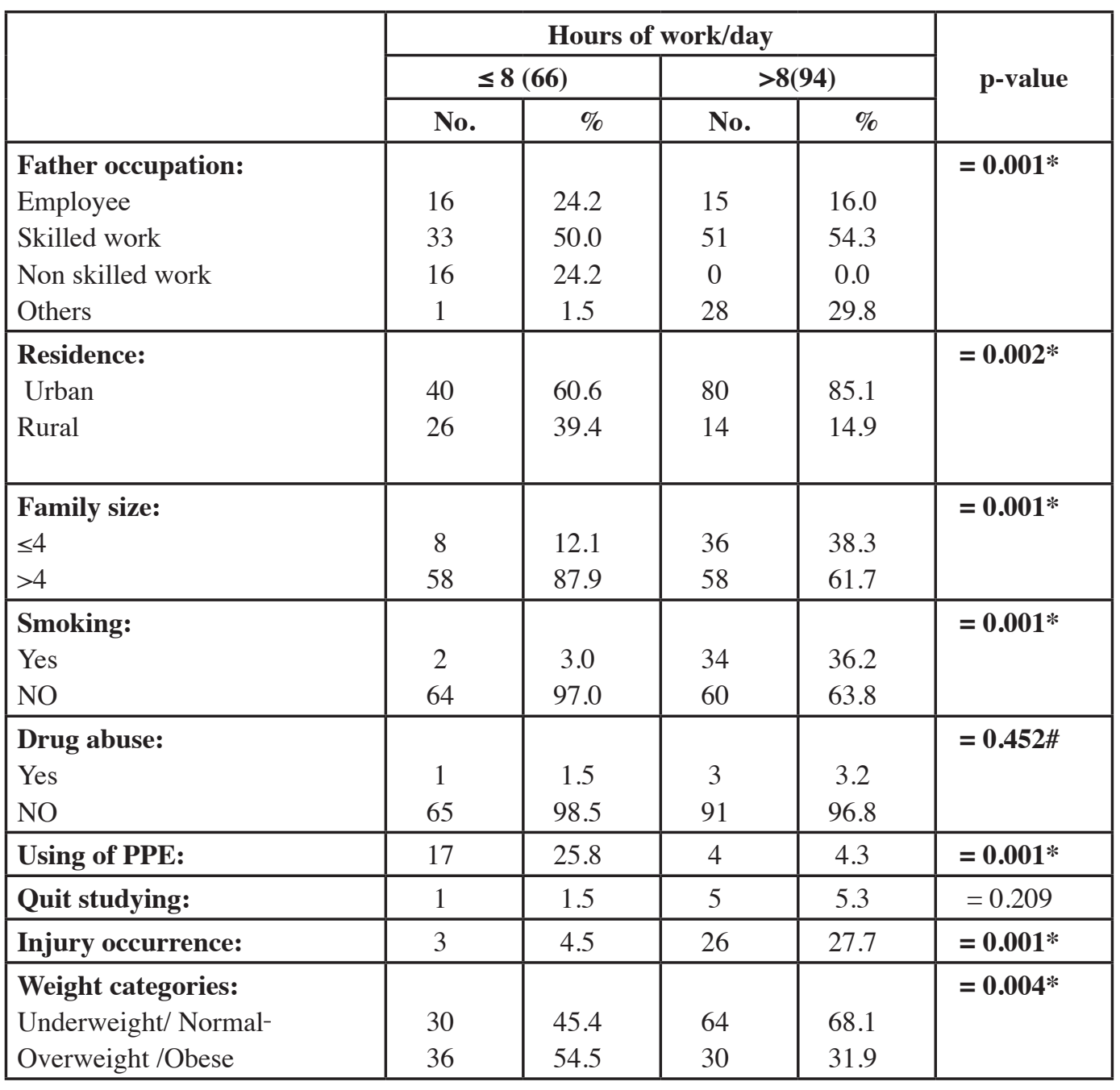

\#: Fissure Exact test PPE: Personal Protective Equipment

*: Statistically significant

Table (5) showed that father's occupation as a skilled worker, family residence in urban area, family size $<4$, higher rate of smoking, lack of using PPE, injury occurrence and normal or underweight children were significantly associated with long duration of working hours ( $>8$ hours per day). 


\section{Discussion}

Most child labor occurs in developing countries and this problem is continuously increasing. Combination of economic and social factors was responsible for the increasing prevalence of child labor (Thévenon and Edmonds 2019).Car repair workers are exposed to different hazards, including dangerous chemicals in addition to hard work, improper work posture, long working hours and load lifting which increase the risk of occupational illnesses and injuries among them (Menicagli et al., 2018 and Ataro et al., 2019).

The results of the current study revealed that most of the studied children had large-sized families (more than 4) (El-Zanaty et al., 2015), their parents were illiterate/read and write, about half of the children's fathers had skilled work and the majority of mothers were not working (Table1). Father's occupation as skilled worker and family size $<4$ was statistically significant associated with work duration $>8$ hours per day (Table 4). Different findings were reported by Qayed et al., (1999) who found that large percent of working children belonged to family size larger than four persons and illiteracy counted a higher percentage among parents of these children $(71.5 \%$ and $92.5 \%$ respectively). The results of the current study were also matched with Nath and Hadi (2000) who conducted a survey on children in rural districts in Bangladesh and found that children from big families and those with many siblings were more likely to be engaged in working at young age. These results were also in coherence with Mohammed et al., (2014) who found that illiteracy of children's parents and large family size were significantly associated with child labor. Large percent ( $75 \%$ ) of the studied group were from urban areas (Table1) due to nearby of their residence to workshops where they were working.

As regards the father's occupation, it was found that the professional background and experience of father can affect the profession and even the social orientations for their children (Qayed et al., 1999).

The present study revealed that about one-quarter of the studied children were smokers (Table1) and smoking rate was positively correlated with the work duration/day (Table 4). This was in agreement with Batty et al., 2012, Abdellah and Morsy, 2013 who found that there was high percentage of smoking and frequent drug abuse 
among the working children. Work plays an important role in stimulating early smoking, since young children try to imitate their adult peers in such a habit. In addition to this, work provides children with an opportunity to spend long hours outsidehome withoutparental supervision which might expose them to bad habits such as smoking and drug abuse and interfere with their ability to differentiate between right and wrong (Nuwayhid et al., 2005).

Moreover, helping their families in expenditures was the most common reason for starting to work as demonstrated in the current work (Table2). This was matched with a study done among children in a rural community at El-Minia governorate, Egypt and concluded that poverty and low family's income were the most frequently reported reasons for starting to work. A similar observation was mentioned by Edmonds and Pavcnik (2005).

The present study found that the majority of working children were not using PPE during their work, more than half of them were working more than 8 hours per day (Table 2) and this non adherence to PPE was statistically significant associated with increase work duration per day (Table 4). This is in agreement with a cross-sectional study conducted in Port-Said city, Egypt among young workers aged 1218 years old in car repair workshops and concluded that the great majority of study group were not using personal protective equipment and more than half of workers had worked for long hours. Their justification was that PPE interfere with their free movement during work, and they didn't help too much for their health (Abdellah and Morsy, 2013). These findings also coincided with Al-Frookh, 2002 in his study of the health problems among car painters in workshops at Hebron City, Palestine and demonstrated that most of the workers did not adhere to personal protective equipment during painting process. The findings of the current work were also in accordance with Shafik and Abd El-Aal, 2016 who reported that the majority of working children (97\%) in the Garment factories in northwest of Banha city, Qalyubia governorate, work $\geq 6$ hours per day.

The present work detected that the majority of the working children were satisfied with their current job (Figure1). This finding was consistent with the result of a study conducted 
among urban Lebanese children (aged 10-17 years) working full time in small industrial shops (Nuwayhid et al., 2005) which concluded that more than half of the working children (64\%) were satisfied with their work.

According to the current study, half of the working children stated that they suffer from work-related physical exhaustion (Figure1), which was lower than what was reported by Shafik and Abd El-Aal , 2016 who found that the majority (91\%) of the working children reported severe work-related physical exhaustion.

About $40 \%$ and $19.4 \%$ of the studied working children were exposed to verbal and physical violence, respectively by their current employers (Figure1). This was nearly similar to the result of a study conducted by Mohammed et al., (2014) who found that about $18 \%$ and $28 \%$ of working children reported that they were exposed to physical and verbal abuse, respectively. On other hand, the results of the current work were in contrary to the findings of a study carried out by Celik S and Baybuga M, 2009 who found that children working on the street were exposed more to verbal and physical violence $(50 \%$ and $50 \%)$.
Furthermore, the current study found that $8.1 \%$ of the working children suffered from allergy related symptoms (Table 3). There was statistically significant higher occurrence of allergy related symptoms among car painters' group $(\mathrm{No}=11(26.8 \%))$ (results are not tabulated). These were matched with a cross-sectional study conducted among automobile spray painters at Mumbai who reported high occurrence of respiratory symptoms among the studied group, and breathlessness and cough were the most prevalent symptoms (Nahar and Ashraf 2018). The findings of the present work were also in agreement with Mohammed et al., (2014) who reported a significant higher prevalence of allergy and respiratory problems among working children compared to the non-working group.

Additionally, $5.6 \%$ of the studied working children suffered from musculoskeletal disorders (MSDs) (Table 3). Children who are working in car repair industry are exposed to hard work, like carrying heavy loads and working in uncomfortable postures such as bending very frequently, which could affect the musculoskeletal development of the children (Yadav and Sengupta 
2009). Physical strain, especially when combined with repetitive movement, on growing children can cause injury, lifelong deformation in bones and joints, and disabilities (Agarwal 2017). The findings of the present work were lower than what was reported by a study conducted in automobile workshops in Peshawar, Pakistan (Khan et al., 2007) and found that $16.5 \%$ of the studied workers were suffering from chronic backache.

It was found that more than half of the studied group were anemic (iron deficiency type) and at the same time with normal weight especially with increasing work duration per day (Table 3 and 4). In agreement with this study; Shoman et al., 2015 concluded that anemia, malnutrition, and poor growth were more prevalent among working children with higher occurrence of obesity and overweight among non working students (Shoman et al., 2015). Children who were forced to do hard work than their working capacity would have suffered serious impact on their physical growth and development, and this may lead to the deficiency of the essential nutrients (Pasdar et al., 2014, Shoman et al., 2015 and Ibrahim et al., 2019)
The prevalence of work-related injuries was $18 \%$ among the studied working children, wounds were the most frequent injuries (83\%) and injury occurrence was statistically significant higher with increase work duration in hours per day (Table 3 and 4). These results were matched with Dalal et al., 2016 who reported that the incidence of injury related illness among 6-17year old child laborers was $19.1 \%$ in Bangladesh and wounds were the main cause of injury related illness. On other hand, the percentage of injury occurrence were lower than that reported by a study conducted by Khan et al., 2007 who detected that $38 \%$ of working children in automobile workshops in Peshawar, Pakistan had injuries, and by another crosssectional study conducted in Port-Said city, Egypt among young workers aged 12- 18 years old in car repair workshops which reported that occupational injuries occurrence was $68.3 \%$ among the studied group (Abdellah and Morsy, 2013).

Likewise, Khan et al., 2007 and Hosseinpour et al., 2014 reported that wounds were the most frequent injuries among working children. Also, Dembe et al., 2004 stated that children who were working for long hours were at higher risk of injury. 


\section{Conclusionand Recommendations:}

Child Labor is affecting the health of working children in negative way and lead to high risk of health problems and work related injuries among them. So we recommend that working children should be covered by medical and social insurance, abolish their illiteracy. It is recommended to apply the Egyptian Labor Law which stated that it is prohibited to employ children before the age of 15 years (Minimum Age Convention No. 138 set the minimum age for admission to employment as the age of education completion).

\section{Conflict of interest}

No conflict of interest is declared by all authors.

\section{Funding}

This study did not receive any funding from any source.

\section{Acknowledgement}

The authors would like to acknowledge the contribution of all individuals who participated in this study.

\section{References}

1. Abdellah RF Morsy KM (2013): Occupational injuries among young workers in car repair workshops in Port-said, Egypt. Egypt J Occup Med; 37(2): 111-20.
2. Agarwal S (2017): Impact of child labour on the nutritional level and developmental 9-12 Years. J Text Sci Eng ; 7(3): 1-4.

3. Al-Frookh AK (2002): Solvent exposure, related work practice and self-reported health problems among car painters in workshops at Hebron City, Palestine: a study from Hebron City, Palestine. Available at https://www.duo.uio.no/ handle/10852/30073

4. Ataro Z, Geremew A and Urgessa F (2019): Chemical exposure in garage workers and related health risks on the biochemical levels: A comparative study in Harar town, eastern Ethiopia. SAGE Open Medicine; 7:2050312119846792.

5. Batty GD, Bhaskar A, Emslie C, Benzeval M, Der G, et al. (2012):Association of life course socioeconomic disadvantage with future problem drinking and heavy drinking: gender differentials in the west of Scotland. Int J Public Health; 57(1): 119-26.

6. Bekele A and Myers WE (1995): First Things First in Child Labour: Eliminating Work Detrimental to Children. Geneva: International Labour Office. Available at: https://digitallibrary. un.org/record/172886? ln=en.

7. CDC (Centers for Disease Control and Prevention) (2012): Basics about childhood obesity. Available at http: // www. cdc.gov / obesity / childhood / basics.html.

8. Celik SS and Baybuga MS (2009): Verbal, physical and sexual abuse among children working on the street. Aust J Adv Nurs ; 26(4): 14-22.

9. Dalal K, Rahman F, Gifford $\mathrm{M}$ and Rahman A (2016): The magnitude of injury problems among child labourers in a rural community of Bangladesh: findings from an injury surveillance system. Int Health ; 8(1): 73-6.

10. Edmonds EV and Pavcnik N (2005): Child labor in the global economy. J Econ Perspect ; 19(1): 199-220.

11. Hosseinpour $M$, Mohammadzadeh $M$ and Atoofi M (2014): Work-related injuries with child labor in Iran. Eur J Pediatr Surg; 24(01): 
$117-20$

12. Ibrahim A, Abdalla SM, Jafer M, Abdelgadir J and De Vries N (2019): Child labor and health: a systematic literature review of the impacts of child labor on child's health in low-and middleincome countries. J Public Health ; 41(1): 18-26.

13. ILO (International Labour Organization) (2016): What is child labour. Available at: https://www. ilo.org/ipec/facts/lang--en/index.htm.

14. ILO (International Labour Organization) (1997): Statistics on Working Children and Hazardous child labour in Brief, Kebebew Ashagrie, Bureau Statistics, Geneva. Available at: file: /// C: / Users / Smart /AppData / Local / Temp / Statistics_on_CL_in_Brief_Oct1997-1.pdf .

15. ILO (International Labour Organization) (2018): Capacity of Egyptian Government, Workers' and Employers' Organizations Strengthened to Combat Child Labour. Available at: https:// www.ilo.org/africa/technical-cooperation/ WCMS_548918/lang--en/index.htm.

16. Khan H, Hameed A and Afridi AK (2007): Study on child labour in automobile workshops of Peshawar, Pakistan. East Mediterr Health J; 13 (6):1497-502.

17. El-Zanaty F and Associates / Egypt, and ICF International. 2015. Egypt Health Issues Survey 2015. Cairo, Egypt: Ministry of Health and Population / Egypt and ICF International. Available at http://dhsprogram.com/pubs/pdf/FR313/ FR313.pdf.

18. Menicagli R, Marotta $\mathrm{O}$ and Menicagli L(2018): The exposure to pollutants of the auto repair workers: Monitoring their oxidative stress. Indian J Occup Environ Med; 22(3):152.

19. Mohammed ES, Ewis AA and Mahfouz EM (2014): Child labor in a rural Egyptian community: an epidemiological study. Int J Public Health ; 59(4): 637-44.

20. Nahar SK and Ashraf MA (2018): Prevalence of respiratory symptoms in automobile spray painters of Mumbai: A cross-sectional study. Indian J Allergy Asthma Immunol ; 32(2): 54.

21. Nath SR and Hadi A (2000): Role of education in reducing child labour: evidence from rural Bangladesh. J Biosoc Sci Suppl; 32(3): 301-13.

22. Nuwayhid IA, Usta J, Makarem M, Khudr A and El-Zein A (2005):Health of children working in small urban industrial shops. Occup Environ Med ;62(2): 86-94.

23. Pasdar Y, Darbandi M and Nachvak SM (2014): Nutritional status of working children as a neglected group in Kermanshah west of Iran. J Community Health Res; 3(2): 124-31.

24. Qayed MH, Moftah FM, Ibrahem HD and Ahmed AE (1999): Socio-economic factors affecting child labor and the related hazards in Assiut city, Egypt. Ass Univ Bull Environ Res ;2(1): 69-82.

25. Radfar A, Asgharzadeh SAA, Quesada F and Filip I(2018): Challenges and perspectives of child labor. Ind Psychiatry J; 27(1): 17.

26. Shafik S andAbd El-Aal M(2016): Occupational Health Program on Preventing Hazard among Child Labor. IOSR Journal of Nursing and Health Science (IOSR-JNHS); 5: 70-80.

27. Shoman AE, Mostafa NS and Musslem AA (2015): Nutritional status and parasitic infestation among working children in a village in Egypt: A comparative study. J Egypt Public Health Assoc ; 90(2): 80-4.

28. Thévenon $O$ and Edmonds E (2019): Child labour: Causes, consequences and policies to tackle it. Available at: https://www.oecd-ilibrary.org / docserver / f6883e26en.pdf?expires $=1627348$ $697 \& \mathrm{id}=\mathrm{id} \&$ accname $=$ guest $\&$ checksum $=2 \mathrm{~B} 77$ A6B7025DD34AAD89FF3A2B658F83.

29. United Nations Children's Fund (UNICEF) (2019): Child labor. October 2019. UNICEF global databases, 2019, based on DHS, MICS and other national surveys, 2010-2018. Available at: https://data.unicef.org/topic/child-protection/child-labour/.

30. UNICEF/ILO (2020): Child Labour: Global estimates 2020, trends and the road forward. Available at: https://data.unicef.org/resources/ child-labour-2020-global-estimates-trends-andthe-road-forward/. 
31. Vyas H, Das S and Mehta S (2011): Occupational injuries in automobile repair workers. Ind Health; 49(5):642-51.

32. Winham DM, Harrison GG, Galal OM and EL-Tobgui M (2004):Anemia and infection in school-aged Egyptian children. Ecol Food Nutr;
43:29-40.

33. Yadav SK and Sengupta G (2009):Environmental and occupational health problems of child labour: Some Issues and Challenges for Future. J Hum Ecol; 28(2): 143-8. 
